Permanent link for this document : https://doi.org/10.33367/tribakti.v30i2.720

\title{
Perubahan Perilaku Pemilih (Voting Behaviour) Partai Politik Islam Dalam Sejarah Kofigurasi Politik Indonesia
}

\author{
Ahmad Gelora Mahardika ${ }^{1}$, Sun Fatayati ${ }^{2}$ \\ ${ }^{1}$ Institut Agama Islam Negeri Tlulungagung, ${ }^{2}$ Institut Agama Islam Tribakti Kediri \\ 1'geloradika@gmail.com, ${ }^{2}$ sunfatayati13@gmail.com
}

\begin{abstract}
This paper aims to examine the phenomenon of the decline of voters in Islamic ideology in Indonesia. Indonesian history notes that Islamic Political Parties have triumphed in political circles with their ability to impose fierce debates against nationalist groups and religions other than Islam when discussing constitutional changes. The endless debate then forced President Soekarno to issue a presidential decree. The sweet history of Islamic Political Parties began to decline when the regime of the New Order government fused authoritatively and caused no more unity of opinion in the Islamic party. At present, Islamic ideology political parties also have a tendency to turn to the Cacth All Party, which is considered more profitable and provides wider opportunities to gain power. This paper aims to prove the changing behavior of voters of Islamic political parties in the history of Indonesia's political configuration.
\end{abstract}

Key Word: Tolerance, Tafsir Al-Misbah, Tafsir Al-Azhar

Abstrak
Tulisan ini hendak mengkaji fenomena merosotnya pemilih Partai
Politik berideologi Islam di Indonesia. Sejarah Indonesia mencatat,
Partai Politik Islam pernah berjaya di percaturan politik dengan
kemampuannya memaksakan perdebatan sengit melawan kelompok
nasionalis dan agama selain Islam ketika membahas perubahan
konstitusi. Perdebatan yang tak ada ujungnya itu kemudian memaksa
Presiden Soekarno mengeluarkan dekrit presiden. Sejarah manis
Partai Politik Islam mulai menurun ketika rejim pemerintahan orde
baru melakukan fusi secara otoritatif dan menimbulkan tidak adanya
lagi kesatuan pendapat di partai Islam. Saat ini, Partai Politik
berideologi Islam juga mempunyai kecenderungan untuk beralih ke
Partai Cacth All yang dianggap lebih menguntungkan dan
memberikan kesempatan yang lebih luas untuk memperoleh
kekuasaan. Tulisan ini hendak membuktikan adanya perubahan


perilaku pemilih partai politik Islam dalam sejarah konfigurasi politik Indonesia.

Kata Kunci: Toleranse, Tafsir Al-Misbah, Tafsir Al-Azhar

\section{Pendahuluan}

Sejak Pemilu 1955, ideologi politik Indonesia dapat dibagi menjadi dua kelompok besar yaitu ideologi politik Islam dan Nasionalis. Pada tahun 1959, kedua kelompok ideologi tersebut mempunyai kepentingan yang berbeda terkait rencana perubahan konstitusi RIS. Perdebatan sengit itu dilatar belakangi perbedaan visi disertai prosentase jarak perolehan suara partai politik yang beraliran Islam dan Nasionalis yang relatif tidak terlampau jauh. Dengan potensi suara yang sedemikian besar, komoditas suara Partai Politik Islam seakan-akan menjadi magnet politik dalam setiap periode pemilihan. Namun seiring berjalannya waktu, dinamika politik yang semakin dinamis, memaksa partai politik mulai bersikap pragmatis dan realistis. Sikap pragmatisme itu berimplikasi dengan dikesampingkannya ideologi partai yang telah digagas oleh para founding fathers mereka.

Partai Kebangkitan Bangsa dan Partai Amanat Nasional sebagai contohnya. Kedua partai politik ini mutlak berasal dari rahim gerakan akar rumput Islam Tradisionalis dan Modernis di Indonesia. Partai Kebangkitan Bangsa didirikan secara langsung oleh Ketua Umum PBNU KH Abdurrahman Wahid, sedangkan Amin Rais yang menjadi deklarator Partai Amanat Nasional merupakan Ketua Umum PP Muhammadiyyah. Tidak ada seorangpun yang menyangkal bahwa kedua Partai yang lahir dari rahim demokrasi ini merupakan turunan dari Partai Masyumi dan NU yang dahulu dikenal sebagai partai major (besar) pada Pemilu 1955. Tidak ada yang membantah pula seberapa besar kontribusi Masyumi dan NU pada tahun 1959 dalam memperjuangkan konstitusi Indonesia agar lebih bernafaskan nilai-nilai Islam. Akan tetapi, dalam beberapa tahun terakhir ini kedua partai tersebut diatas dengan tegas menyebut mereka adalah partai terbuka - atau disisi lain bukan Partai khusus Islam - meskipun dalam kenyataannya perolehan suara terbesar mereka didapat dari kantong-kantong pendukung NU dan Muhammaddiyah.

Disisi lain, Partai Politik yang secara terus terang menggunakan Islam sebagai ideologinya dan masih bertahan hanyalah Partai Keadilan Sejahtera dan Partai Bulan Bintang. Yang menjadi fenomenal adalah keberadaan Partai Keadilan Sejahtera (PKS), PKS adalah partai yang memperdagangkan gerakan Islam Puritan yang sebenarnya tidak laku di era politik tahun1950-an. Gerakan PKS lebih mempunyai persamaan dengan gerakan global yang dipengaruhi oleh Ikhwanul Muslimin di Mesir. ${ }^{1}$

${ }^{1}$ Damanik, A.S. Fenomena Partai Keadilan. Transformasi 20 tahun Gerakan Tarbiyah di Indonesia, (Jakarta: Penerbit Teraju,2002), Hal.26

Tribakti: Jurnal Pemikiran Keislaman Volume 30, Nomor 2, Juli 2019 
Seiring berjalannya waktu, preferensi pemilih terhadap partai politik mulai bervariasi. Partai Politik Islam tidak mampu lagi menyakinkan janji surga bagi para pemilihnya sebagaimana yang terjadi pada pemilu sebelumnya. Kemajuan informasi dan peningkatan infrastruktur menjadi aktor utama yang mempengaruhi pergeseran suara pemilih dengan signifikan. Apakah fenomena ini menandakan bahwa gerakan Partai Politik Islam sudah tidak relevan lagi dalam sistem politik Indonesia, ataukah ini merupakan kemenangan ideologi nasionalis dalam memperjualkan ideologinya?. Ataukah ini merupakan bentuk migrasi pemilih ideologi partai politik Islam menjadi pemilih mengambang (swing voters)?. Fenomena inilah yang hendak penulis teliti dalam penelitian ini.

\section{Metode Penelitian}

Pelaksanaan penelitian "Perubahan Perilaku Pemilih (Voting Behaviour) Partai Politik Islam Dalam Sejarah Kofigurasi Politik Indonesia" menggunakan pendekatan deskriptif. Menurut Jacob Vredenberg, tujuan penelitian deskriptif adalah untuk melukiskan realitas sosial yang kompleks dan sedemikian rupa ${ }^{2}$. Selain itu untuk menguatkan hasil penelitian, dilakukan pula studi perbandingan dengan negara lain. Dari perbandingan ini dapat diperoleh persamaan-persamaan dan perbedaan-perbedaan dari obyek atau obyek-obyek penelitian dengan alat pembandingnya atau dari obyek penelitian yang satu dengan obyek penelitian yang lainnya.

\section{Pembahasan}

Apabila membicarakan tentang definisi Partai Politik, akan banyak teoriteori yang bermunculan. Salah satu definisi yang cukup dikenal dalam kajian ilmu politik adalah definisi yang diberikan oleh Miriam Budiardjo. Menurut Miriam Budiarjo, partai politik adalah suatu kelompok yang terorganisir, yang anggota-anggotanya mempunyai orientasi, nilai-nilai dan cita-cita yang sama. Tujuan kelompok ini ialah untuk memperoleh kekuasaan politik dan merebut kedudukan politik (biasanya) dengan cara konstitutional - untuk melaksanakan kebikjasanaan-kebijaksanaan mereka. ${ }^{3}$ Sebagian besar definisi partai politik yang dicetuskan oleh para pakar dan ahli hampir tidak jauh dari apa yang disampaikan oleh Miriam Budiardjo, pada dasarnya Partai Politik adalah organisasi yang bertujuan untuk memperoleh kekuasaan.

Apabila melihat tipenya, partai politik bisa dilihat dari berbagai tipe. Miriam Budiardjo menyebut ada empat jenis partai politik, yaitu partai kader dan partai massa dilihat dari segi komposisi dan fungsi keanggotaan, serta

${ }^{2}$ Jacob Vredenbergt, Metode dan Teknik Penelitian Masyarakat Indonesia, (Jakarta : Gramedia,1983), Hal.32

${ }^{3}$ Miriam Budiardjo, Dasar-Dasar Ilmu Politik (Jakarta:Gramedia,2001), Hal.160-161

Tribakti: Jurnal Pemikiran Keislaman

Volume 30, Nomor 2, Juli 2019 
partai lindungan dan partai ideologi dlihat dari sifat dan orientasi, sebagai berikut ${ }^{4}$ :

a. Partai Lindungan (Patronage Party), umumnya memiliki organisasi nasional yang longgar (sekalipun organisasi ditingkat lokal sering cukup ketat), disiplin yang lemah dan biasanya tidak terlalu mementingkan pemungutan iuran secara teratur. Maksud utamanya ialah memenangkan Pemilu untuk anggota-anggotanya yang dicalonkannya, karena itu tipe partai ini hanya giat menjelang masa-masa pemilihan.

b. Partai Ideologi atau Partai Asas (seperti sosialisme,fasisme, komunisme, kristen-demokrat), biasanya mempunyai pandangan hidup yang digariskan dalam kebijakan pimpinan dan berpedoman pada disiplin partai yang kuat dan mengikat.

c. Partai Massa, mengutamakan kekuatan berdasarkan keunggulan jumlah anggota; oleh karena itu biasanya terdiri dari pendukung-pendukung dari berbagai aliran politik dalam masyarakat yang sepakat untuk bernaung di bawahnya dalam memperjuangkan suatu program yang biasanya luas dan agak kabur.

d. Partai Kader, mementingkan keketatan organisasi dan disiplin kerja dari anggota-anggotanya. Pimpinan Partai biasanya menjaga kemurnian doktrin politik yang dianut dnegan jalan mengadakan saringan terhadap calon anggotanya dan memecat anggota yang menyeleweng dari garis partai yang ditetapkan.

Disisi lain menurut Ichlasul Amal, dalam bukunya Pengantar TeoriTeori Mutakhir Politik, perbedaan jenis partai-partai yang ada juga dapat diklasifikasikan berdasarkan tingkat komitmen Partai terhadap ideologi dan kepentingan: ${ }^{5}$

(1) Partai Proto adalah tipe awal Partai Politik sebelum mencapai tingkat perkembangan seperti dewasa ini. Partai semacam ini muncul di Eropa barat sekitar abad pertengahan hingga akhir abad ke-19. Ciri paling menonjol partai proto adalah pembedaan antara kelompok anggota atau "ins" dengan non anggota atau "outs". Selebihnya, partai ini belum menunjukkan ciri sebagai partai politik dalam pengertian modern. Karena itu sesungguhnya partai proto adalah faksi yang dibentuk berdasarkan pengelompokan ideologis masyarakat

(2) Partai Kader merupakan perkembangan lebih lanjut partai proto, Partai ini muncul sebelum diterapkannya sistem hak pilih secara luas bagi rakyat hingga sangat bergantung pada masyarakat kelas menangah atas yang memiliki hak pilih, keanggotaan yang terbatas, kepeimimpinan, serta para

\footnotetext{
${ }^{4}$ Ibid, Hal.21-22

5 Ichlasul Amal, Pengantar Teori-Teori Mutakhir Politik (Yogyakarta:Tiara Wacana,1988), Hal.31
} 
pemberi dana. Tingkat organisasi dan ideologi partai kader sesungguhnya masih rendah karena aktivitasnya jarang didasarkan pada program dan organisasi yang kuat.

(3) Partai Massa muncul pada saat terjadi perluasan hak pilih rakyat sehingga dianggap sebagai suatu respon politis dan organisasional bagi perluasan hak-hak pilih serta pendorong bagi perluasan hak-hak pilih serta pendorong bagi hak-hak pilih tersebut. Partai massa dibentuk di luar lingkungan parlemen (ekstra-parlemen), berorientasi pada basis pendukung yang luas misalnya, buruh, petani dan kelompok agama, dan memiliki ideologi yang cukup jelas untuk memobilisasi massa serta mengembangkan organisasi yang cukup rapi untuk mencapai tujuantujuan ideologisnya. Tujuan utama partai ini tidak hanya memperoleh kemenangan dalam pemilihan, tapi juga untuk memberikan pendidikan politik bagi para anggotanya dalam rangka membentuk elit yang langsung direkrut dari massa.

(4) Partai Diktatorial merupakan sub-tipe dari partai massa, tetapi memiliki ideologi yang lebih kaku dan radikal. Pemimpin tertinggi partai ini melakukan kontrol yang sangat ketat terhadap pengurus bawahan maupun anggota-anggota partai. Rekrutmen keanggotaan partai diktatorial dilakukan secara lebih selektif daripada partai massa. Untuk diterima sebagai anggota partai ini seseorang harus lebih dahulu diuji kesetiaan dan komitmennya terhadap ideologi partai. Partai diktatorial menuntut pengabdian secara total setiap anggotanya.

(5) Partai Catch-all merupakan gabungan dari partai kader dan partai massa. Catch-all dapat diartikan sebagai "menampung kelompok-kelompok sosial sebanyak mungkin untuk dijadikan anggotanya". Tujuan utama partai ini adalah memenangkan pemilihan dengan cara menawarkan program-program dan keuntungan bagi anggotanya sebagai ganti ideologi yang kaku. Aktivitas partai ini berkaitan erat dengan kelompok kepentingan dan kelompok penekan.

Lantas dimanakah posisi Partai-Partai berideologi Islam di Indonesia?. Apabila meminjam teori Miriam Budiardjo untuk mengklasifikasikan Partai Politik, maka Partai berasaskan Islam bisa dimasukkan sebagai Partai Ideologi (ketika dilihat ideologinya), Partai Massa (apabila dilihat kekuatan massanya), dan bisa juga Partai Kader (apabila menggunakan sistem kaderisasi dalam penentuan jabatannya). Dalam konteks politik Indonesia, ideologi dan massa tidak dapat dipisahkan, ibarat koin bermata dua, keduanya merupakan satu kesatuan. Hal ini bisa dilihat pada kasus Nahdlatul Ulama (NU) yang awalnya merupakan gerakan Islam tradisionalis, dan mempunyai massa yang besar. Tanpa adanya ideologi (common of ideology), maka tidak akan muncul gerakan massa yang begitu besar. Kasus ini terjadi pula pada partai-partai politik lain. Hanya saja ideologi kerap kali hanya berubah menjadi alat politik 
semata, dan pada akhirnya tidak pernah diimplementasikan sama sekali dalam pengambilan keputusan politik.

Tipe Partai Cacth All dimana pragmatisme menjadi ideologi tunggal adalah tipe yang paling sesuai dengan kondisi partai politik saat ini. Kondisi politik saat ini yang mementingkan menang dan kalah membuat Partai Politik mencoba lebih dinamis dalam rangka memungut potensi suara sebesarbesarnya dari voters. Lantas apakah benar ideologi Islam sudah tidak relevan lagi untuk menjadi political barters untuk menggaet suara rakyat?, sehingga memaksa partai politik untuk masuk ke arena free market voters yaitu menjadi partai catch all. Apakah benar pemilih partai politik Islam sudah berpindah menjadi swing voters yang tidak memilih lagi berdasarkan ideologi namun berdasarkan apa yang mereka dapat dan apa yang partai tawarkan?.

Untuk melihat bagaimana perilaku pemilih, ada tiga teori besar yang menjelaskan mengapa seseorang memilih suatu partai politik ${ }^{6}$. Pertama, teori sosiologis. Seseorang ikut/tidak ikut berpartisipasi dalam pemilihan dilatarbelakangi persoalan sosiologis, seperti kesamaan agama, pendidikan, pekerjaan, ras, dan sebagainya, pola pendekatan ini lebih dikenal dengan mahzab Columbia. Kedua, adalah teori psikologis, yang mana keputusan seseorang untuk ikut memilih atau tidak ditentukan oleh kedekatan. Menurut kelompok ini, secara metodologis pendekatan sosiologis dianggap sulit diukur, sebagimana mengukur secara tepat sejumlah indikator kelas sosial, tingkat pendidikan, agama dan sebagainya. Disini para pemilih menentukan pilihannya karena pengaruh kekuatan psikologis yang berkembang dalam dirinya sebagai produk dari proses sosialisasi, artinya sikap seseorang merupakan refleksi dari kepribadian dan merupakan variabel yang menentukan dalam mempengaruhi perilaku politiknya, kelompok ini dikenal dengan sebutan Michigan Model. Dan yang ketiga, adalah pendekatan pilihan rasional (rational choice), model yang ketiga ini mengkritik kedua pendekatan sebelumnya. Menurut pendekatan rational choice, Karakteristik sosiologis, latar belakang keluarga, pembelahan kultural, identifikasi partai melalui proses sosialisasi, pengalaman hidup, merupakan variabel yang secara sendiri-sendiri mempengaruhi perilaku politik seseorang. Ini berarti variabel lain menentukan atau ikut menentukan dalam mempengaruhi perilaku pemilih. Ada faktor situasional yang ikut mempengaruhi pilihan politik seseorang. Dengan begitu para pemilih bukan hanya pasif tetapi juga aktif, bukan hanya terbelenggu oleh karakteristik sosiologis tetapi bebas untuk bertindak. Faktor situasional ini bisa berupa isu-isu politik pada kandidat yang dicalonkan. Perilaku pemilih tidak harus tetap atau sama, karena karakteristik sosiologis dan identifikasi partai dapat berubah-ubah sesuai waktu dan peristiwa-peristiwa politik tertentu.

${ }^{6}$ The Study of Electoral Behavior." In Jan E. Leighley, ed., The Oxford Handbook of American Elections and Political Behavior, ( New York: Oxford University Press, 2010), Hal. 239-261 
Dengan begitu, isu-isu politik menjadi pertimbangan yang penting dimana para pemilih akan menentukan pilihan berdasarkan penilaian terhadap isu-isu politik dan kandidat yang diajukan.

\section{Partai Politik Islam di Indonesia}

Partai Politik di Indonesia pada periode Pemilu 1955 dapat dibagi menjadi dua kelompok besar yaitu Partai Politik ideologi Islam yang terdiri dari Partai Masyumi (Majelis Syuro Muslimin Indonesia), Partai NU, PSII, Perti dan Partai ideologi Nasionalis yang termasuk diantaranya adalah PNI,PKI (sebelum dibubarkan), IPKI dan Murba. Fragmentasi politik Indonesia bisa dengan mudah dilakukan diawal-awal berdirinya bangsa. Hal itu disebabkan adanya common issue antara dua kelompok tersebut dalam menghadapi isu yang relatif sensitif yaitu mengenai pembahasan konstitusi baru untuk menggantikan Konstitusi Sementara. Sebagian besar kelompok pendukung Partai Islam menghendaki agar konstitusi Indonesia kedepannya harus lebih menjunjung nilai-nilai Islam dengan merujuk pada Piagam Jakarta, namun sebaliknya pendukung gerakan nasionalis menghendaki agar Indonesia kembali ke UUD 1945.

Ide negara Islam tersebut membuat pergeseran politik mengerucut ke dua kelompok besar. Partai Kristen yang sebenarnya mempunyai ideologi berbeda dengan nasionalis akhirnya memilih bergabung dengan faksi nasionalis dikarenakan kekhawatiran apabila dimenangkan oleh kelompok Islam maka mereka akan menjadi warga kelas dua (lower citizen).

Tabel 1

Pembagian Kursi DPRS dan DPR

Hasil Pemilu 1955

\begin{tabular}{|c|c|c|}
\hline \multirow{2}{*}{ Parpol } & \multicolumn{2}{|c|}{ DPR Hasil Pemilu 1955 } \\
\cline { 2 - 3 } & Jumlah Kursi & Prosentase (\%) \\
\hline Orpol Non Agama & 127 & $49,4 \%$ \\
\hline Orpol Islam & 116 & $45,2 \%$ \\
\hline Orpol Kristen & 14 & $5,4 \%$ \\
\hline Jumlah & $\mathbf{2 5 7}$ & $\mathbf{1 0 0 , 0 \%}$ \\
\hline
\end{tabular}

Sumber : Diolah dari situs resmi Komisi Pemilihan Umum

Peta politik saat itu memang relatif sangat berimbang. Posisi partai kristen sebenarnya sangat strategis, meskipun prosentase suaranya kecil. Sikap politik Partai Kristen akan menentukan manakah kelompok yang akan memimpin perolehan suara di parlemen. Terlihat dalam tabel diatas, jumlah perolehan partai politik Islam cukup signifikan walaupun belum mampu menandingi nasionalis. Akan tetapi apabila Orpol agama (Islam dan Kristen) mempunyai satu isu yang sama, bisa jadi secara kumulatif jumlahnya lebih besar daripada partai nasionalis. 
Pertentangan ideologi tersebut pada akhirnya berakhir ketika Presiden Soekarno mengeluarkan Dekrit Presiden yang salah satu isinya adalah pembubaran konstituante. Padahal konstituante adalah produk resmi demokrasi Pemilu 1955. Akan tetapi tidak adanya reaksi perlawanan dari masyarakat membuat proses "pembegalan" demokrasi tersebut berjalan lancar tanpa adanya protes yang berlebihan. Setelah itu praksis partai politik Islam mulai kehilangan common issue (isu bersama) yang sebelumnya mepersatukan mereka dalam satu gerakan intra parlement.

Hilangnya isu yang menyatukan mereka, membuat Partai Politik Islam mengalami friksi-friksi internal yang sejatinya sudah hadir sejak lama. Paska orde lama digantikan oleh Orde Baru, partai islam dipaksa untuk berfusi kedalam satu partai, yaitu Partai Persatuan Pembangunan. Akan tetapi sejarah terulang kembali, Isu Islam Modernis dan Tradisionalis, yang memecah Partai Masyumi menjadi dua yaitu Partai Masyumi dan NU kembali terjadi di internal Partai Persatuan Pembangunan.

Pada akhirnya Partai Persatuan Pembangunan yang merupakan satusatunya Partai yang bernafaskan nilai-nilai Islam pun harus tercerai berai disebabkan problem internalnya yang berlarut-larut. Titik kulminasi retaknya PPP terjadi ketika NU pada Muktamar NU 1984 di Situbondo secara resmi membuat keputusan bersejarah yaitu kembali ke khittah NU 1926, yaitu NU lepas dari perannya sebagai organisasi politik. Menurut keputusan Muktamar, arah perjalanan NU selama ini telah menyimpang dari maksud dan tujuan didirikannya NU oleh para pendirinya ${ }^{7}$. Perubahan arah politik NU mengurangi suara PPP secara drastis pada Pemilu 1987, dari partai yang dianggap kompetitif dan layak bersaing, PPP justru semakin lekat dengan Partai medioker serta semakin tertinggal jauh dari Golkar.

Tabel 2

Hasil Pemilihan Umum Tahun 1977,1982, dan 1987

\begin{tabular}{|c|c|c|c|c|c|c|}
\hline \multirow{2}{*}{ Orpol } & \multicolumn{3}{|c|}{ Prosentase Suara } & \multicolumn{3}{c|}{ Jumlah Kursi } \\
\cline { 2 - 7 } & 1977 & 1982 & 1987 & 1977 & 1982 & 1987 \\
\hline Golkar & $62,1 \%$ & $64,3 \%$ & $73,16 \%$ & 232 & 242 & 299 \\
\hline PPP & $29,3 \%$ & $27,8 \%$ & $15,97 \%$ & 99 & 94 & 61 \\
\hline PDI & $8,6 \%$ & $8,6 \%$ & $10,87 \%$ & 29 & 24 & 40 \\
\hline Total & $\mathbf{1 0 0 \%}$ & $\mathbf{1 0 0 \%}$ & $\mathbf{1 0 0 \%}$ & $\mathbf{3 6 0}$ & $\mathbf{3 6 0}$ & $\mathbf{4 0 0}$ \\
\hline
\end{tabular}

Sumber : diolah dari situs resmi Komisi Pemilihan Umum

Terlihat dari tabel di atas, posisi PPP sebagai Partai Politik Hasil Fusi PartaiPartai Islam sebenarnya cukup signifikan, akan tetapi sejak Muktamar NU Tahun 1984 di Situbondo yang menyatakan bahwa NU kembali ke khittah 1926 dan menyatakan keluar dari PPP, perolehan suara PPP merosot sangat

7 Nur Khalik Ridwan, NU dan Bangsa : Pergulatan Politik dan Kekuasaan, (Yogyakarta:Ar-Ruzz Media,2010), Hal.62 
tajam merosot hingga hampir 50\% dibandingkan perolehan suaranya pada Pemilu sebelumnya.

\section{Partai Politik Islam di Era Reformasi}

Reformasi Politik pada tahun 1999 membuka lembaran baru sistem politik Indonesia dari sebelumnya menganut sistem dua partai ( two-party system) menjadi sistem multi partai (multy-party System). Pada hakikatnya, sistem dua partai paling relevan untuk Indonesia yang menganut sistem presidensial, akan tetapi penerapan sistem dua partai yang melalui mekanisme fusi dari penguasa dianggap menciderai nilai-nilai luhur demokrasi yaitu hak untuk berserikat, berkumpul dan membentuk partai politik. Berangkat dari semangat itulah pendirian partai politik kemudian dibuka selebar-lebarnya serta diberi peluang yang sama bagi setiap warga negara untuk membentuk partai politik baru.

Undang-Undang Nomor 2 Tahun 1999 tentang Partai Politik pada akhirnya disahkan oleh pemerintah. Dalam Undang-Undang tersebut, persyaratan untuk membentuk partai politik baru sangat mudah, yaitu hanya dibentuk oleh 50 (lima puluh) orang WNI yang berumur 21 tahun dan didaftarkan di Departemen Kehakiman bersama dengan akta notaris.

Dibukanya kran demokrasi sebesar-besarnya membuat gairah untuk membentuk kembali partai Islam bermunculan. Tercatat pada tahun 1999, Departemen Kehakiman (sekarang Kementerian Hukum dan Hak Asasi Manusia) mengesahkan 148 Partai Politik baru berbadan hukum dengan pandangan ideologi yang berbeda-beda.

Tabel 3

Partai Politik Baru Berbadan Hukum Tahun 1999

\begin{tabular}{|c|c|c|}
\hline Idelogi Parpol & Jumlah & Prosentase (\%) \\
\hline Nasionalis & 91 & $61,48 \%$ \\
\hline Islam & 31 & $20,95 \%$ \\
\hline Kristen & 1 & $0,67 \%$ \\
\hline Katolik & 4 & $2,71 \%$ \\
\hline Sosialis & 10 & $6,75 \%$ \\
\hline Lain-Lain & 11 & $7,44 \%$ \\
\hline Total & $\mathbf{1 4 8}$ & $\mathbf{1 0 0} \%$ \\
\hline
\end{tabular}

Sumber : diolah dari data di Kementerian Hukum dan HAM RI

Identifikasi Partai Islam pada tabel diatas didasarkan pada Partai yang memasang simbol Islam pada namanya serta mempunyai basis suara Islam sebagai pendulum suaranya -Partai Kebangkitan Bangsa dan Partai Amanat Nasional termasuk dalam Partai yang mempunyai ideologi Islam-. Sementara itu Partai yang berideologi lain-lain dalam Tabel ini adalah Partai yang mempunyai visi dan misi khusus serta dianggap mewakili kelompok minoritas 
(minority group). Contoh partai politik yang termasuk dalam kelompok lainlain yaitu, Partai Hijau yang memfokuskan gerakannya pada lingkungan, lalu Partai Seni dan Dagelan Indonesia yang memperjuangkan hak-hak komedian, Partai Reformasi Tionghoa Indonesia yang berorientasi pada egalitarisasi kelompok Tionghoa di Indonesia. Selain itu terdapat pula Partai Buddhis Demokrat Indonesia yang merupakan partai yang mengakomodir pemeluk agama Buddha di Indonesia.

Secara kumulatif, jumlah partai Islam cukup besar apabila dibandingkan dengan partai-partai lain. Secara jumlah, partai politik Islam hanya kalah dari partai politik beraliran nasionalis, memori indah akan kejayaan partai politik Islam benar-benar dimanfaatkan oleh sejumlah pihak untuk mencoba merebut hati para pemilih baru yang merindukan kebebasan berdemokrasi yang terpenjara selama rejim orde baru.

Jumlah 148 Partai Politik tersebut diatas ternyata tidak semuanya mampu memenuhi persyaratan untuk mengikuti Pemilu 1999. Pemilu 1999, tercatat hanya 48 partai politik yang bisa berpartisipasi dalam Pemilu 1999. Partai politik tersebut diantaranya adalah :

Tabel 3

Daftar Partai Politik Peserta Pemilu 1999

\begin{tabular}{|c|c|c|c|}
\hline Nama Partai Politik & Ideologi & Suara & Prosentase \\
\hline Partai Indonesia Baru (PIB) & Nasionalis & 192.712 & $0,18 \%$ \\
\hline $\begin{array}{c}\text { Partai Kristen Nasional } \\
\text { Indonesia }\end{array}$ & Kristen & 369.719 & $0.35 \%$ \\
\hline $\begin{array}{c}\text { Partai Nasional Indonesia - } \\
\text { Supeni }\end{array}$ & Nasionalis & 377.137 & $0,36 \%$ \\
\hline $\begin{array}{c}\text { Partai Aliansi Demokrat } \\
\text { Indonesia }\end{array}$ & Nasionalis & 85.838 & $0,08 \%$ \\
\hline $\begin{array}{c}\text { Partai Kebangkitan Muslim } \\
\text { Indonesia (Partai Kami) }\end{array}$ & Islam & 289.489 & $0,27 \%$ \\
\hline Partai Ummat Islam (PUI) & Islam & 269.309 & $0.25 \%$ \\
\hline $\begin{array}{c}\text { Partai Kebangkitan Ummat } \\
\text { (PKU) }\end{array}$ & Islam & 300.064 & $0,22 \%$ \\
\hline Partai Masyumi Baru & Islam & 152.589 & $0,14 \%$ \\
\hline Partai Persatuan Pembangunan & Islam & 11.329 .905 & $10,71 \%$ \\
\hline Partai Syarikat Islam Indonesia & Islam & 375.920 & 0,36 \\
\hline $\begin{array}{c}\text { Partai Demokrasi Indonesia } \\
\text { Perjuangan (PDI-P) }\end{array}$ & Nasionalis & 35.689 .073 & $33,74 \%$ \\
\hline Partai Abul Yatam & Nasionalis & 219.379 & $0,20 \%$ \\
\hline Partai Kebangsaan Merdeka \\
(PKM) & Nasionalis & 104.385 & $0,10 \%$ \\
\hline Partai Demokrasi Kasih Bangsa & Katolik & 550.846 & $0,52 \%$ \\
\hline Partai Amanat Nasional (PAN) & Islam & 7.528 .956 & $7,12 \%$ \\
\hline
\end{tabular}




\begin{tabular}{|c|c|c|c|}
\hline $\begin{array}{c}\text { Partai Rakyat Demokratik (P R } \\
\text { D) }\end{array}$ & Sosialis & 78.730 & $0,07 \%$ \\
\hline Partai Syarikat Islam Indonesia & Islam & 152.820 & $0,14 \%$ \\
\hline $\begin{array}{l}\text { Partai Katolik Demokrat ( P K D } \\
\text { ) }\end{array}$ & Katolik & 216.675 & $0,20 \%$ \\
\hline Partai Pilihan Rakyat (Pilar) & Nasionalis & 40.517 & $0,04 \%$ \\
\hline Partai Rakyat Indonesia (PARI) & Nasionalis & 54.790 & $0,05 \%$ \\
\hline $\begin{array}{c}\text { Partai Politik Islam Indonesia } \\
\text { Masyumi }\end{array}$ & Islam & 456.718 & $0,43 \%$ \\
\hline Partai Bulan Bintang ( PBB ) & Islam & 2.049 .708 & $1,94 \%$ \\
\hline Partai Solidaritas Pekerja (PSP) & Sosialis & 61.105 & $0,06 \%$ \\
\hline Partai Keadilan (PK) & Islam & 1.436 .565 & $1,36 \%$ \\
\hline Partai Nahdlatul Ummat & Islam & 679.179 & $0,64 \%$ \\
\hline $\begin{array}{c}\text { Partai Nasional Indonesia - Front } \\
\text { Marhaenis }\end{array}$ & Nasionalis & 365.176 & $0,35 \%$ \\
\hline $\begin{array}{l}\text { Partai Ikatan Pendukung } \\
\text { Kemerdekaan Indonesia }\end{array}$ & Nasionalis & 328.654 & $0,31 \%$ \\
\hline Partai Republik & Nasionalis & 328.564 & $0,31 \%$ \\
\hline Partai Islam Demokrat (PID) & Islam & 62.901 & $0,06 \%$ \\
\hline $\begin{array}{c}\text { Partai Nasional Indonesia - } \\
\text { Massa Marhaen }\end{array}$ & Nasionalis & 345.629 & $0,33 \%$ \\
\hline $\begin{array}{c}\text { Partai Musyawarah Rakyat } \\
\text { Banyak }\end{array}$ & Nasionalis & 62.006 & $0,06 \%$ \\
\hline $\begin{array}{l}\text { Partai Demokrasi Indonesia } \\
\text { (PDI) }\end{array}$ & Nasionalis & 345.720 & $0,33 \%$ \\
\hline Partai Golongan Karya (Golkar) & Nasionalis & 23.741 .749 & $22,44 \%$ \\
\hline Partai Persatuan (PP) & Islam & 655.052 & $0,62 \%$ \\
\hline $\begin{array}{c}\text { Partai Kebangkitan Bangsa } \\
(\mathrm{PKB})\end{array}$ & Islam & 13.336 .982 & $12,61 \%$ \\
\hline Partai Uni Demokrasi Indonesia & Nasionalis & 140.980 & $0,13 \%$ \\
\hline Partai Buruh Nasional (PBN) & Sosialis & 140.980 & $0,13 \%$ \\
\hline $\begin{array}{c}\text { Partai Musyawarah } \\
\text { Kekeluargaan Gotong Royong } \\
\text { (Partai MKGR) }\end{array}$ & Nasionalis & 204.204 & $0,19 \%$ \\
\hline Partai Daulat Rakyat (PDR) & Nasionalis & 427.854 & $0,40 \%$ \\
\hline Partai Cinta Damai & Nasionalis & 168.087 & $0,16 \%$ \\
\hline $\begin{array}{c}\text { Partai Keadilan Dan Persatuan } \\
\text { (PKP) }\end{array}$ & Nasionalis & 1.065 .686 & $1,01 \%$ \\
\hline Partai Pekerja Indonesia & Nasionalis & 63.934 & $0,06 \%$ \\
\hline $\begin{array}{l}\text { Partai Solidaritas Pekerja } \\
\text { Seluruh Indonesia (SPSI) }\end{array}$ & Sosialis & 49.807 & $0,05 \%$ \\
\hline $\begin{array}{l}\text { Partai Nasional Bangsa } \\
\text { Indonesia }\end{array}$ & Nasionalis & 149.136 & $0,14 \%$ \\
\hline $\begin{array}{l}\text { Partai Bhinneka Tunggal Ika } \\
\text { Indonesia (PBI) }\end{array}$ & Nasionalis & 364.291 & $0,34 \%$ \\
\hline
\end{tabular}




\begin{tabular}{|c|c|c|c|}
\hline $\begin{array}{c}\text { Partai Solidaritas Uni Nasional } \\
\text { Indonesia (Partai Suni) }\end{array}$ & Nasionalis & 180.167 & $0,17 \%$ \\
\hline Partai Nasional Demokrat (PND) & Nasionalis & 96.984 & $0,09 \%$ \\
\hline $\begin{array}{c}\text { Partai Ummat Muslimin } \\
\text { Indonesia }\end{array}$ & Islam & 48.839 & $0,05 \%$ \\
\hline Total & & $\mathbf{1 0 5 . 7 8 6 . 6 6 1}$ & $\mathbf{1 0 0 , 0 0 \%}$ \\
\hline
\end{tabular}

Sumber : Arsip Kementerian Hukum dan HAM RI

Apabila kita melihat dengan proporsi berdasarkan ideologi, maka akan ditemukan angka sebagai berikut :

Tabel 4

Hasil Pemilu 1999

\begin{tabular}{|c|c|c|}
\hline Ideologi Parpol & Jumlah & Prosentase \\
\hline Nasionalis & 64.813 .998 & $61,26 \%$ \\
\hline Islam & 39.124 .401 & $36,98 \%$ \\
\hline Lain-Lain & 1.848 .262 & $1,76 \%$ \\
\hline Total & $\mathbf{1 0 5 . 7 8 6 . 6 6 1}$ & $\mathbf{1 0 0 \%}$ \\
\hline
\end{tabular}

Sumber: Diolah dari Situs Resmi Komisi Pemilihan Umum

Terlihat dari tabel di atas secara jumlah, suara Partai Nasionalis mampu meraup suara yang signifikan. Hal itu disebabkan masih terdapatnya suarasuara kelompok Islam yang mendukung Partai Politik beraliran Nasionalis, seperti Partai Golkar yang dikenal mempunyai akar rumput yang sangat mengakar di masyarakat. Akan tetapi apabila kita lihat, perolehan suara Partai yang berideologi Islam cukup signifikan. Berangkat dari kelompok Islam inilah muncul poros tengah yang berhasil menempatkan $\mathrm{KH}$ Abdurrahman Wahid sebagai Presiden RI.

Pada Pemilu 2004, arah politik mulai berubah mengikuti arus romantisme masyarakat. Kegagalan $\mathrm{KH}$ Abdurrahman Wahid dalam mempertahankan posisi Presiden serta adanya konflik antara eksekutif dan legislatif tidak membuat tingkat kepercayaan masyarakat terhadap Partai Politik Islam menurun. Hal ini menunjukkan bahwa suara pemilih partai poltik Islam masih menempatkan basis ideologi sebagai acuan.

Tabel 5

Hasil Pemilu 2004

\begin{tabular}{|c|c|c|c|}
\hline Partai & Ideologi & Jumlah Suara & Prosentase \\
\hline Partai Golongan Karya & Nasionalis & 24.461 .104 & $21,62 \%$ \\
\hline $\begin{array}{c}\text { Partai Demokrasi } \\
\text { Indonesia Perjuangan }\end{array}$ & Nasionalis & 20.710 .006 & $18,31 \%$ \\
\hline $\begin{array}{c}\text { Partai Kebangkitan } \\
\text { Bangsa }\end{array}$ & Islam & 12.002 .885 & $10,61 \%$ \\
\hline $\begin{array}{c}\text { Partai Persatuan } \\
\text { Pembangunan }\end{array}$ & Islam & 9.226 .444 & $8,16 \%$ \\
\hline Partai Demokrat & Nasionalis & 8.437 .868 & $7,46 \%$ \\
\hline
\end{tabular}

Tribakti: Jurnal Pemikiran Keislaman Volume 30, Nomor 2, Juli 2019 


\begin{tabular}{|c|c|c|c|}
\hline Partai Keadilan Sejahtera & Islam & 8.149 .457 & $7,20 \%$ \\
\hline Partai Amanat Nasional & Islam & 7.255 .331 & $6,41 \%$ \\
\hline Partai Bulan Bintang & Islam & 2.965 .040 & $2,62 \%$ \\
\hline Partai Bintang Reformasi & Islam & 2.944 .529 & $2,60 \%$ \\
\hline Partai Damai Sejahtera & Kristen & 2.424 .319 & $2,14 \%$ \\
\hline $\begin{array}{c}\text { Partai Karya Peduli } \\
\text { Bangsa }\end{array}$ & Nasionalis & 2.394 .651 & $2,12 \%$ \\
\hline $\begin{array}{l}\text { Partai Keadilan dan } \\
\text { Persatuan Indonesia }\end{array}$ & Nasionalis & 1.420 .085 & $1,26 \%$ \\
\hline $\begin{array}{c}\text { Partai Persatuan } \\
\text { Demokrasi Kebangsaan }\end{array}$ & Nasionalis & 1.310 .207 & $1,16 \%$ \\
\hline $\begin{array}{c}\text { Partai Nasional Banteng } \\
\text { Kemerdekaan }\end{array}$ & Nasionalis & 1.228 .497 & $1,09 \%$ \\
\hline Partai Patriot Pancasila & Nasionalis & 1.178 .738 & $1,04 \%$ \\
\hline $\begin{array}{c}\text { Partai Nasional Indonesia } \\
\text { Marhaenisme }\end{array}$ & Nasionalis & 906.739 & $0,80 \%$ \\
\hline $\begin{array}{l}\text { Partai Persatuan } \\
\text { Nahdlatul Ummah } \\
\text { Indonesia }\end{array}$ & Islam & 890.980 & $0,79 \%$ \\
\hline Partai Pelopor & Nasionalis & 896.603 & $0,79 \%$ \\
\hline $\begin{array}{c}\text { Partai Penegak } \\
\text { Demokrasi Indonesia }\end{array}$ & Nasionalis & 844.480 & $0,75 \%$ \\
\hline Partai Merdeka & Nasionalis & 839.705 & $0,74 \%$ \\
\hline Partai Sarikat Indonesia & Nasionalis & 677.259 & $0,60 \%$ \\
\hline $\begin{array}{c}\text { Partai Perhimpunan } \\
\text { Indonesia Baru }\end{array}$ & Nasionalis & 669.835 & $0,59 \%$ \\
\hline Partai Persatuan Daerah & Nasionalis & 656.473 & $0,58 \%$ \\
\hline $\begin{array}{c}\text { Partai Buruh Sosial } \\
\text { Demokrat }\end{array}$ & Sosialis & 634.515 & $0,56 \%$ \\
\hline Total & & 113.127.750 & $100 \%$ \\
\hline
\end{tabular}

Sumber : diolah dari situs resmi Komisi Pemilihan Umum

Kita lihat dari tabel diatas, suara partai Islam justru meningkat meskipun tipis. Meskipun di daerah-daerah yang sebelumnya menjadi kantong suara Partai-Partai Islam seperti Jawa Timur dan Jawa Tengah, suara Partai Islam menurun akan tetapi hal itu lebih disebabkan adanya perpecahan didalam partai politik Islam sehingga memcah partai Islam menjadi partai-partai kecil. Berdasarkan tabel diatas, berikut adalah konfigurasi partai politik pada Pemilu 2004.

Tabel 6

Konfigurasi Politik Pemilu 2004

\begin{tabular}{|c|c|c|}
\hline Ideologi Parpol & Jumlah & Prosentase \\
\hline Nasionalis & 68.724 .170 & $60,7 \%$ \\
\hline Islam & 43.434 .666 & $38,39 \%$ \\
\hline Lain-Lain & 3.058 .834 & $1,76 \%$ \\
\hline
\end{tabular}




\begin{tabular}{|c|c|c|}
\hline Total & $\mathbf{1 1 3 . 1 2 5 . 7 5 0}$ & $\mathbf{1 0 0 \%}$ \\
\hline
\end{tabular}

Sumber : diolah dari situs resmi Komisi Pemilihan Umum RI

Terlihat dari data diatas tidak ada perubahan yang relatif signifikan dibandingkan hasil pada Pemilu 1999. Dimana proporsi kekuatan Partai Islam tidak bergeser dari angka 30-an\% meskipun pada beberapa partai nasionalis terjadi perubahan yang signifikan terutama pada perolehan suara PDI-P. Kegagalan Megawati (Ketua Umum PDI-P) dalam mengelola pemerintahan semenjak menggantikan KH Abdurrahman Wahid dipandang menjadi faktor utama. Akan tetapi yang mengejutkan adalah peningkatan pesat Partai Keadilan Sejahtera (PKS) yang merupakan Partai berasas Islam namun lebih mengandalkan kaderisasi dibandingkan kekuatan massa dan ideologi.

Pada tahun 2009, pergerakan Partai berideologi Islam mulai diuji keteguhannya akankah tetap konsisten mengusung asas ideologi Islam ataukah berani mendeklarasikan dirinya sebagai partai terbuka. Pada Pemilu 2009, sejumlah Partai Politik pada akhirnya memilih untuk mendeklarasikan partainya menjadi partai terbuka. Mereka mengharapkan loyalitas massanya tetap bertahan, disisi lain ada harapan untuk memancing suara masyarakat terutama pemilih pemula yang dianggap potensial untuk mendongkrak perolehan suara partai politik.

Tabel 7

Hasil Pemilu 2009

\begin{tabular}{|c|c|c|c|}
\hline Partai & Ideologi & Jumlah Suara & Prosentase \\
\hline Partai Hati Nurani Rakyat & Nasionalis & 3.925 .620 & $3,77 \%$ \\
\hline $\begin{array}{c}\text { Partai Karya Peduli } \\
\text { Bangsa }\end{array}$ & Nasionalis & 1.461 .375 & $1,40 \%$ \\
\hline $\begin{array}{l}\text { Partai Pengusaha dan } \\
\text { Pekerja Indonesia }\end{array}$ & Nasionalis & 745.965 & $0,72 \%$ \\
\hline $\begin{array}{c}\text { Partai Peduli Rakyat } \\
\text { Nasional }\end{array}$ & Nasionalis & 1.260 .950 & $1,21 \%$ \\
\hline $\begin{array}{c}\text { Partai Gerakan Indonesia } \\
\text { Raya }\end{array}$ & Nasionalis & 4.642 .795 & $4,46 \%$ \\
\hline Partai Barisan Nasional & Nasionalis & 760.712 & $0,73 \%$ \\
\hline $\begin{array}{l}\text { Partai Keadilan dan } \\
\text { Persatuan Indonesia }\end{array}$ & Nasionalis & 936.133 & $0,90 \%$ \\
\hline Partai Keadilan Sejahtera & Islam & 8.204 .946 & $7,89 \%$ \\
\hline Partai Amanat Nasional & Islam & 6.273 .462 & $6,03 \%$ \\
\hline $\begin{array}{l}\text { Partai Perjuangan } \\
\text { Indonesia Baru }\end{array}$ & Nasionalis & 198.803 & $0,19 \%$ \\
\hline Partai Kedaulatan & Nasionalis & 438.030 & $0,42 \%$ \\
\hline Partai Persatuan Daerah & Nasionalis & 553.299 & $0,53 \%$ \\
\hline $\begin{array}{c}\text { Partai Kebangkitan } \\
\text { Bangsa }\end{array}$ & Islam & 5.146 .302 & $4,95 \%$ \\
\hline Partai Pemuda Indonesia & Nasionalis & 415.563 & $0,40 \%$ \\
\hline
\end{tabular}




\begin{tabular}{|c|c|c|c|}
\hline $\begin{array}{c}\text { Partai Nasional Indonesia } \\
\text { Marhaenisme }\end{array}$ & Nasionalis & 317.433 & $0,31 \%$ \\
\hline $\begin{array}{l}\text { Partai Demokrasi } \\
\text { Pembaruan }\end{array}$ & Nasionalis & 896.959 & $0,86 \%$ \\
\hline Partai Karya Perjuangan & Nasionalis & 351.571 & $0,34 \%$ \\
\hline Partai Matahari Bangsa & Islam & 415.294 & $0,40 \%$ \\
\hline $\begin{array}{c}\text { Partai Penegak } \\
\text { Demokrasi Indonesia }\end{array}$ & Nasionalis & 139.988 & $0,13 \%$ \\
\hline $\begin{array}{c}\text { Partai Demokrasi } \\
\text { Kebangsaan }\end{array}$ & Nasionalis & 671.356 & $0,65 \%$ \\
\hline $\begin{array}{l}\text { Partai Republik } \\
\text { Nusantara }\end{array}$ & Nasionalis & 631.814 & $0,61 \%$ \\
\hline Partai Pelopor & Nasionalis & 345.092 & $0,33 \%$ \\
\hline Partai Golongan Karya & Nasionalis & 15.031 .497 & $14,45 \%$ \\
\hline $\begin{array}{l}\text { Partai Persatuan } \\
\text { Pembangunan }\end{array}$ & Islam & 5.544 .332 & $5,33 \%$ \\
\hline Partai Damai Sejahtera & Kristen & 1.522 .032 & $1,46 \%$ \\
\hline $\begin{array}{c}\text { Partai Nasional Banteng } \\
\text { Kerakyatan Indonesia }\end{array}$ & Nasionalis & 468.856 & $0,45 \%$ \\
\hline Partai Bulan Bintang & Islam & 1.864 .642 & $1,79 \%$ \\
\hline $\begin{array}{c}\text { Partai Demokrasi } \\
\text { Indonesia Perjuangan }\end{array}$ & Nasionalis & 14.576 .388 & $14,01 \%$ \\
\hline Partai Bintang Reformasi & Islam & 1.264 .150 & $1,21 \%$ \\
\hline Partai Patriot & Nasionalis & 547.798 & $0,53 \%$ \\
\hline Partai Demokrat & Nasionalis & 21.655 .295 & $20,81 \%$ \\
\hline $\begin{array}{l}\text { Partai Kasih Demokrasi } \\
\text { Indonesia }\end{array}$ & Katolik & 325.771 & $0,31 \%$ \\
\hline Partai Indonesia Sejahtera & Nasionalis & 321.019 & $0,31 \%$ \\
\hline $\begin{array}{l}\text { Partai Kebangkitan } \\
\text { Nasional Ulama }\end{array}$ & Islam & 1.527 .509 & $1,47 \%$ \\
\hline Partai Merdeka & Nasionalis & 111.609 & $0,11 \%$ \\
\hline $\begin{array}{l}\text { Partai Persatuan } \\
\text { Nahdlatul Ummah } \\
\text { Indonesia }\end{array}$ & Islam & 146.831 & $0,14 \%$ \\
\hline Partai Sarikat Indonesia & Nasionalis & 141.558 & $0,14 \%$ \\
\hline Partai Buruh & Sosialis & 265.359 & $0,26 \%$ \\
\hline Total & & 104.048.118 & $100 \%$ \\
\hline
\end{tabular}

Sumber : situs resmi Komisi Pemilihan Umum

Pada pemilu 2009, jumlah Partai Politik yang ikut berpartisipasi dalam Pemilu jauh lebih besar dibandingkan dengan Pemilu 2004. Partai-partai baru tersebut sebenarnya bukanlah murni partai politik baru, melainkan hasil dari friksi internal di partai politik yang tidak mampu diselesaikan melalui mekanisme muktamar/kongres. Partai Hanura dan Partai Gerindra adalah pecahan dari Partai Golkar,Partai Demokrasi Pembaruan adalah hasil konflik 
internal di tubuh PDI-P. Disisi lain, tren konflik internal dan membentuk partai baru juga dialami oleh partai politik berideologi Islam. Partai Kebangkitan Bangsa melahirkan sempalan Partai Kebangkitan Nasional Ulama, Partai Persatuan Pembangunan melahirkan Partai Bintang Reformasi, sedangkan Partai Amanat Nasional juga memunculkan Partai Matahari Bangsa.

Tabel 9

Konfigurasi Pemilu Tahun 2009

\begin{tabular}{|c|c|c|}
\hline Ideologi Parpol & Jumlah & Prosentase \\
\hline Nasionalis & 71.547 .478 & $68,76 \%$ \\
\hline Islam & 30.387 .018 & $29,20 \%$ \\
\hline Lain-Lain & 2.113 .162 & $2,04 \%$ \\
\hline Total & $\mathbf{1 0 4 . 0 4 8 . 1 1 8}$ & $\mathbf{1 0 0 \%}$ \\
\hline
\end{tabular}

Sumber : diolah dari situs resmi Komisi Pemilihan Umum

Dari tabel diatas, terlihat suara partai Islam mengalami penurunan yang signifikan. Meskipun sejumlah Partai Islam telah mendeklarasikan dirinya sebagai partai terbuka dengan cara merekrut calon anggota legislatif dari kelompok-kelompok minoritas, akan tetapi pola tersebut ternyata tidak berpengaruh signifikan bagi peningkatan suara partai politik Islam di Indonesia.

Pada Pemilu 2014, Partai Kebangkitan Bangsa merekrut Rudi Kirana ( CEO Lion Air ) sebagai salah satu pengurusnya. Langkah politik PKB semakin mengindikasikan keinginannya untuk menjadi Partai yang tidak hanya terjebak pada dogmatisme ideologi semata, disisi lain Partai Amanat Nasional juga melakukan hal serupa dengan membuka kesempatan bagi para tokoh-tokoh layar kaca yang populer untuk menjadi vote getters bagi partai politik.

Persyaratan yang berat di Undang-Undang Nomor 8 Tahun 2012 tentang Pemilu membuat jumlah partai politik yang diperbolehkan berpartisipasi dalam Pemilu menjadi berkurang drastis. Hal ini membuat suara-suara dari partai politik nasionalis maupun islam berkumpul di 12 partai politik sebagaimana yang tercantum pada Tabel 10 .

Tabel 10

Hasil Pemilu 2014

\begin{tabular}{|c|c|c|c|}
\hline Partai & Ideologi & Jumlah Suara & Prosentase \\
\hline Partai Nasdem & Nasionalis & 8.402 .812 & 6,72 \\
\hline Partai Golongan Karya & Nasionalis & 18.432 .312 & $14,75 \%$ \\
\hline $\begin{array}{c}\text { Partai Demokrasi } \\
\text { Indonesia Perjuangan }\end{array}$ & Nasionalis & 23.681 .471 & $18,95 \%$ \\
\hline $\begin{array}{c}\text { Partai Kebangkitan } \\
\text { Bangsa }\end{array}$ & Islam & 11.198 .957 & $8,4 \%$ \\
\hline \multicolumn{2}{|l}{} \\
\hline
\end{tabular}




\begin{tabular}{|c|c|c|c|}
\hline $\begin{array}{c}\text { Partai Persatuan } \\
\text { Pembangunan }\end{array}$ & Islam & 8.157 .488 & $6,53 \%$ \\
\hline Partai Demokrat & Nasionalis & 12.728 .913 & $10,9 \%$ \\
\hline Partai Keadilan Sejahtera & Islam & 8.480 .104 & $7,1 \%$ \\
\hline Partai Amanat Nasional & Islam & 9.481 .621 & $7,59 \%$ \\
\hline Partai Bulan Bintang & Islam & 1.825 .750 & $1,46 \%$ \\
\hline $\begin{array}{c}\text { Partai Keadilan dan } \\
\text { Persatuan Indonesia }\end{array}$ & Nasionalis & 1.143 .094 & $0,91 \%$ \\
\hline Partai Hati Nurani Rakyat & Nasionalis & 6.579 .498 & $2,9 \%$ \\
\hline $\begin{array}{c}\text { Partai Gerakan Indonesia } \\
\text { Raya }\end{array}$ & Nasionalis & 14.760 .371 & $11,81 \%$ \\
\hline Total & & $\mathbf{1 2 4 . 9 7 2 . 4 9 1}$ & $\mathbf{1 0 0 \%}$ \\
\hline
\end{tabular}

Sumber : Situs resmi Komisi Pemilihan Umum RI

Berdasarkan hasil pemilu di Tabel 10, konfigurasi partai politik hasil pemilu 2014 adalah sebagai berikut.

Tabel 11

Konfigurasi Hasil Pemilu 2014

\begin{tabular}{|c|c|c|}
\hline Ideologi Parpol & Jumlah & Prosentase \\
\hline Nasionalis & 85.728 .471 & $68,7 \%$ \\
\hline Islam & 39.143 .920 & $31,3 \%$ \\
\hline Total & $\mathbf{1 2 4 . 9 7 2 . 4 9 1}$ & $\mathbf{1 0 0 \%}$ \\
\hline
\end{tabular}

Sumber : diolah dari situs resmi Komisi Pemilihan Umum RI

Pada Pemilu 2014, Partai-Partai Politik mulai mendeklarasikan dirinya sebagai Partai terbuka selain usahanya untuk menggaet kembali konstituennya yang telah berpindah hati ke partai politik lain. Hal ini dilakukan oleh Partai Kebangkitan Bangsa semenjak Gus Dur yang merupakan salah satu ikon politiknya keluar, serta diikuti lahirnya Partai Kebangkitan Nasional Ulama (PKNU). Begitu pula dengan PPP yang tercerai-berai sejak konflik internal dan kemudian melahirkan Partai Bintang Reformasi. Usaha itu terbilang cukup berhasil dengan meningkatnya suara partai-partai Islam pada Pemilu 2014.

Tabel 11

Tabulasi Suara Partai Politik Islam

\begin{tabular}{|c|c|c|c|c|c|c|c|c|}
\hline Parpol & $\mathbf{1 9 5 5}$ & $\mathbf{1 9 7 7}$ & $\mathbf{1 9 8 2}$ & $\mathbf{1 9 8 7}$ & $\mathbf{1 9 9 9}$ & $\mathbf{2 0 0 4}$ & $\mathbf{2 0 0 9}$ & $\mathbf{2 0 1 4}$ \\
\hline Nasionalis & 49,4 & 62,1 & 64,3 & 73,16 & 61,26 & 60,75 & 68,76 & $68,7 \%$ \\
\hline Islam & 45,2 & 29,3 & 27,8 & 15,97 & 36,98 & 38,4 & 29,20 & $31,3 \%$ \\
\hline
\end{tabular}

Sumber : diolah dari berbagai sumber resmi Komisi Pemilihan Umum RI

Apabila kita lihat dalam tabel 11, perolehan suara Partai Politik Islam mengalami perubahan yang dinamis. Pemilu 1955 merupakan bukti bahwa partai Islam sebenarnya memiliki jumlah pemilih yang sangat potensial apabila dihadapkan pada isu yang sama (agama). Akan tetapi seiring berjalannya 
waktu membuat Partai Politik yang mengandalkan ideologi sudah tidak relevan lagi. Hal ini disebabkan semakin banyaknya karakter pemilih yang dipegaruhi berbagai faktor. Kelompok pemilih pemula (new voters) tentu saja akan lebih melihat platform serta visi dan misi partai politik dibandingkan kedekatan sosiologis (agama, suku, ras, dll). Kondisi ini coba diantisipasi oleh sejumlah Partai Politik Islam di Indonesia dengan menyatakan dirinya sebagai Partai terbuka, sebagaimana yang dilakukan oleh PKB, PAN, dan terakhir PKS meskipun hasilnya bisa dianggap belum terlalu menggembirakan.

Dari tabel diatas dapat pula disimpulkan, telah terjadi perubahan preferensi pemilih partai politik Islam di Indonesia, yang sebelumnya memilih berdasarkan faktor-faktor sosiologis (agama, ras, pendidikan, suku, dll) berubah didasarkan pada pilihan yang rasional (rational choice), pemilih partai politik Islam dari yang sebelumnya pemilih tetap (fixed voters) menjadi pemilih mengambang (swing voters).

\section{Kesimpulan}

Pemilu adalah sarana paling demokratis untuk merepresentasikan suara rakyat. Pemilih sebagai pemilik kedaulatan selalu mempunyai preferensi dalam menjatuhkan pilihannya. Dalam konteks partai Islam, sejarah Pemilu membuktikan bahwa terjadi pasang surut suara pemilih. Pada era orde baru, fenomena tersebut disebabkan fusi partai politik yang dipaksakan oleh pemerintah sehingga menimbulkan banyak pihak yang tidak sepaham memutuskan untuk tidak berkontribusi. Akan tetapi alasan tersebut ternyata tidak sepenuhnya benar. Pada era reformasi, Partai Politik yang dideklarasikan oleh NU dan Muhammadiyyah yang merupakan ormas Islam terbesar di Indonesia memperoleh suara yang tidak terlalu signifikan. Bahkan dalam 2 (dua) periode Pemilu terahkir, suara Partai Politik Islam terus mengalami penurunan. Fenomena ini membuktikan dua hal penting, yaitu pertama, ideologi, agama, dan kesukuan sudah tidak terlalu signifikan mempengaruhi perolehan suara, Partai Politik Islam terlihat gagal mengantisipasi kondisi tersebut sehingga mereka berusaha masuk ke area free market voters dan memposisikan dirinya sebagai Partai terbuka (cacth all). Kedua, Pemilih partai politik ideologi dan massa semakin berkurang jumlahnya dan menjadi pemilih mengambang (swing voters), hal ini bisa jadi disebabkan arus informasi yang semakin tidak terbatas disisi lain Partai Politik kurang tanggap sehingga menimbulkan kekecewaan pemilih. Kemungkinan besar pemilih yang mengganti pilihannya didasarkan pada gagalnya partai politik mengimplementasikan visi-misinya serta menepati janji-janji politiknya.

Kondisi ini harus dicermati oleh Partai Politik Islam agar perolehan suaranya tidak terus menerus menurun. Ide-ide yang berlatarbelakang sosiologis sudah tidak relevan dalam konteks demokrasi yang menjunjung nilai-nilai akuntabilitas dan transparansi. Partai Politik Islam masih mampu bersaing apabila penerapan-penerapan nilai-nilai Islam berhasil dijalankan. 
Hal ini terjadi Pada kasus meroketnya suara Partai Keadilan Sejahtera pada tahun 2004 yang disebabkan penerapan nilai-nilai Islami seperti anti korupsi dan tata krama dalam berpolitik. Untuk kedepannya partai politik Islam harus mengadopsi nilai-nilai Islam seperti anti korupsi, etika politik untuk bersaing kembali dalam arena dengan partai-partai nasionalis.

\section{Daftar Pustaka}

Amal, Ichlasul, Pengantar Teori-Teori Mutakhir Politik,Yogyakarta : Tiara Wacana, 1988

Budiardjo, Miriam, Dasar-Dasar Ilmu Politik, Jakarta : Gramedia, 2001

Damanik, A.S. , Fenomena Partai Keadilan. Transformasi 20 tahun Gerakan Tarbiyah di Indonesia, Jakarta: Penerbit Teraju, 2002

Ridwan, Nur Khalik, NU dan Bangsa : Pergulatan Politik dan Kekuasaan, Yogyakarta:Ar-Ruzz Media, 2010

The Study of Electoral Behavior." In Jan E. Leighley, ed., The Oxford Handbook of American Elections and Political Behavior,New York: Oxford University Press, 2010

Vredenbergt, Jacob, Metode dan Teknik Penelitian Masyarakat Indonesia, Jakarta : Gramedia, 1983 